\title{
The simulations of sulfuric acid concentration and new particle formation in an urban atmosphere in China
}

\author{
Z. B. Wang ${ }^{1,2}$, M. Hu ${ }^{1}$, D. Mogensen ${ }^{3}$, D. L. Yue ${ }^{1}$, J. Zheng ${ }^{4}$, R. Y. Zhang ${ }^{1,4}$, Y. Liu ${ }^{1}$, B. Yuan ${ }^{1}$, X. Li ${ }^{1,5}$, M. Shao ${ }^{1}$, \\ L. Zhou ${ }^{3}$, Z. J. Wu ${ }^{1,2}$, A. Wiedensohler ${ }^{2}$, and M. Boy ${ }^{3}$ \\ ${ }^{1}$ State Key Joint Laboratory of Environmental Simulation and Pollution Control, College of Environmental Sciences and \\ Engineering, Peking University, Beijing 100871, China \\ ${ }^{2}$ Leibniz Institute for Tropospheric Research, Permoserstr. 15, 04318 Leipzig, Germany \\ ${ }^{3}$ Department of Physics, University of Helsinki, P.O. Box 64, 00014 Helsinki, Finland \\ ${ }^{4}$ Department of Atmospheric Science, Texas A\&M University, College Station, Texas 77843, USA \\ ${ }^{5}$ Institute für Energie- und Klimaforschung Troposphäre (IEK-8), Forschungszentrum Jülich, 52425 Jülich, Germany
}

Correspondence to: M. Hu (minhu@pku.edu.cn)

Received: 21 February 2013 - Published in Atmos. Chem. Phys. Discuss.: 7 June 2013

Revised: 17 October 2013 - Accepted: 18 October 2013 - Published: 15 November 2013

\begin{abstract}
Simulations of sulfuric acid concentration and new particle formation are performed by using the zerodimensional version of the model MALTE (Model to predict new Aerosol formation in the Lower TropospherE) and measurements from the Campaign of Air Quality Research in Beijing and Surrounding areas (CAREBeijing) in 2008. Chemical reactions from the Master Chemical Mechanism version 3.2 (MCM v3.2) are used in the model. High correlation (slope $=0.72, R=0.74$ ) between the modelled and observed sulfuric acid concentrations is found during daytime (06:00-18:00). The aerosol dynamics are simulated by the University of Helsinki Multicomponent Aerosol (UHMA) model including several nucleation mechanisms. The results indicate that the model is able to predict the on- and offset of new particle formation in an urban atmosphere in China. In addition, the number concentrations of newly formed particles in kinetic-type nucleation including homogenous homomolecular $\left(J=K\left[\mathrm{H}_{2} \mathrm{SO}_{4}\right]^{2}\right)$ and homogenous heteromolecular nucleation involving organic vapours $\left(J=K_{\text {het }}\left[\mathrm{H}_{2} \mathrm{SO}_{4}\right][\mathrm{Org}]\right)$ are in satisfactory agreement with the observations. However, the specific organic compounds that possibly participate in the nucleation process should be investigated in further studies. For the particle growth, only a small fraction of the oxidized total organics condense onto the particles in polluted environments. Meanwhile, the $\mathrm{OH}$ and $\mathrm{O}_{3}$ oxidation mechanism contribute $5.5 \%$ and $94.5 \%$ to the volume concentration of small particles, indicating the
\end{abstract}

particle growth is more controlled by the precursor gases and their oxidation by $\mathrm{O}_{3}$.

\section{Introduction}

New particle formation (NPF) events have been observed to take place in diverse atmospheric environments all over the world including the stratosphere, free troposphere, cloud outflows, coastal and marine areas, above and inside the forest, remote continental boundary layers and polluted urban environments (Holmes, 2007; Kulmala and Kerminen, 2008; Kulmala et al., 2004b). Both field measurements and model results show that particle nucleation is a significant source of potential cloud condensation nuclei (CCN), which may influence cloud microphysical and climate-relevant properties (Merikanto et al., 2009; Spracklen et al., 2008; Wang et al., 2013a; Wiedensohler et al., 2009; Yue et al., 2011). Consequently, advancing our understanding on the formation mechanisms of new particles in the atmosphere has become critically important.

Several nucleation theories such as binary nucleation (Kulmala et al., 1998), ternary nucleation (Napari et al., 2002) and ion-induced nucleation (Yu and Turco, 2000) have been proposed and explored since last century. Gaseous sulfuric acid has been identified as a key precursor in the nucleation process because of its low vapour pressure at typical 
atmospheric temperatures (Berndt et al., 2005; Sipilä et al., 2010; Weber et al., 1995). In most environments, the relationship between the observed particle nucleation rates and ambient sulfuric acid concentrations with the exponents lies in the range 1-2 (Kuang et al., 2008; Nieminen et al., 2009; Paasonen et al., 2009; Riipinen et al., 2007; Sihto et al., 2006). These values indicate the activation (exponent 1 ) and kinetic (exponent 2) nucleation processes (Kulmala et al., 2006; McMurry and Friedlander, 1979), respectively. Meanwhile, higher power values in Beijing have been reported recently (Wang et al., 2011), implying that thermodynamic process seems to work better than the activation and kinetic nucleation theories.

The presence of sulfuric acid in gaseous concentrations of $10^{6}-10^{7}$ molecules $\mathrm{cm}^{-3}$ is necessary in order to observe new particle formation events in the atmosphere (Zhang et al., 2012). However, the measurement of sulfuric acid concentration is difficult to achieve due to the high requirements of technology. The first measurements of atmospheric gaseous sulfuric acid have been performed in the stratosphere using passive chemical ionization mass spectrometry (Arnold and Buhrke, 1983; Arnold and Fabian, 1980; Arnold et al., 1982). Although the measurements of sulfuric acid in the lower troposphere have been achieved since last century (Eisele and Tanner, 1993; Weber et al., 1995, 1997), gaseous sulfuric acid information is still very rare, especially in polluted urban environments.

Several methods have been applied to obtain the sulfuric acid concentration in order to make up for the absence of direct measurement. The essential parameterization assumes only one source (chemical reaction between sulfur dioxide and the $\mathrm{OH}$ radical) and one sink (condensation onto the preexisting particles) for sulfuric acid in the atmosphere (Kulmala et al., 2001; Weber et al., 1997). Based on this assumption, Petäjä et al. (2009) developed three proxies for the sulfuric acid concentration, and the estimated results correlated well with the observations. However, the proxies might be site-specific. Recent research has found a single proxy for the sulfuric acid concentration that can be applied over a greater range of environments (Mikkonen et al., 2011). Nevertheless, this proxy just originates from the statistical analysis, and the real chemical process would be covered. Modelling is an adequate possibility to trace the detailed sources and sinks of species in the atmosphere. Several box model simulations have been performed to calculate the sulfuric acid concentrations (Boy et al., 2005, 2006).

However, all these methods were only applied in clean environments partly due to the lack of direct sulfuric acid measurement in the polluted environments. The first gaseous sulfuric acid measurements in Beijing were conducted during the CAREBeijing 2008 campaign (Zheng et al., 2011). Hence, the purpose of this study is to test the MALTE (Model to predict new Aerosol formation in the Lower TropospherE) model for Beijing. The sulfuric acid concentration was mod- elled and the new particle formation event was predicted with various nucleation mechanisms.

\section{Materials and methods}

\subsection{Instrumentation}

The sampling site is located on the sixth floor of an academic building on the campus of Peking University (PKU; $\left.39.99^{\circ} \mathrm{N}, 116.31^{\circ} \mathrm{E}\right)$. Two major roads with heavy traffic at the east and south of the site are respectively $200 \mathrm{~m}$ and $500 \mathrm{~m}$ away. Detailed descriptions of the measurement site and surrounding environment can be found in $\mathrm{Wu}$ et al. (2008). The PKU site is assumed to be representative of a polluted urban atmosphere.

On-line high-resolution measurements of both gaseous pollutants and aerosol characteristics were carried out simultaneously during the CAREBeijing 2008 campaign, from 12 July to 25 September. A dual mobility particle size spectrometer TROPOS-type TDMPS (twin differential mobility particle sizer) consisting of two parallel Hauke-type differential mobility analyzers (DMAs) was used to measure number size distributions of atmospheric particles from 3 to $900 \mathrm{~nm}$ in mobility diameter (Birmili et al., 1999). The relative humidity (RH) within the whole system was kept below $30 \%$ by adding silica-gel dryers both in the inlet line and in the sheath air cycle to avoid condensation of water during humid days. In addition, the particle number size distributions were corrected for particle losses inside the TDMPS and in the sampling configuration, following the method of the "equivalent length" as described in Wiedensohler et al. (2012).

Ambient gaseous sulfuric acid concentration is measured by an AP-ID-CIMS (atmospheric pressure ion driftchemical ionization mass spectrometry) apparatus built by Texas A\&M University (Fortner et al., 2004; Zheng et al., 2010). Briefly, the device consists of four major elements including an inlet, an Am-241 ion source, a special ion-drift tube and a quadrupole mass spectrometer. The main protontransfer reaction is

$$
\mathrm{H}_{2} \mathrm{SO}_{4}+\mathrm{NO}_{3}^{-} \cdot \mathrm{HNO}_{3} \rightarrow \mathrm{HSO}_{4}^{-} \cdot \mathrm{HNO}_{3}+\mathrm{HNO}_{3} \text {. }
$$

Both reagent and product ions are detected sequentially for $12 \mathrm{~s}$. The detection limit of sulfuric acid is as low as $10^{5}$ molecules $\mathrm{cm}^{-3}$ with an uncertainty of $36 \%$.

High time-resolution volatile organic compound (VOC) concentrations were obtained using proton transfer reactionmass spectrometer (PTR-MS), which was used for the first time in China. The uncertainties of PTR-MS for various compounds were estimated to $20 \%$, and the detection limits ranged from 20 to $250 \mathrm{ppt}$ (Yuan et al., 2010). In addition, instantaneous whole air samples were taken using fused silicalined stainless steel canisters (3.2 L, Entech Instruments, Inc., Simi Valley, CA, USA). The samples were quantified by gas chromatograph (GC, HP-7890A, Hewlett-Packard Co., 
Palo Alto, CA, USA) equipped with a quadrupole mass spectrometer (MSD, HP-5975C, Hewlett Packard), and a flame ionization detector (FID). Detailed analytical methods and results can be found in Wang et al. (2010).

The photolysis frequencies of $\mathrm{O}_{3}\left(J_{\mathrm{O}^{1} \mathrm{D}}\right)$ and $\mathrm{NO}_{2}\left(J_{\mathrm{NO}_{2}}\right)$ were measured by using specifically designed filter radiometers provided by the Research Centre Jülich (Forschungszentrum, FZJ), Germany. The accuracy of the photolysis frequency measurements is estimated to be $10 \%$ at solar zenith angles smaller than $80^{\circ}$ (Bohn et al., 2008).

Measurements of the gas concentrations were carried out by using commercial analyzers (Ecotech, Inc.). The instrument models are EC9810 for $\mathrm{O}_{3}$, EC9830 for CO, EC9850 for $\mathrm{SO}_{2}$ as well as EC9841 for $\mathrm{NO}$ and $\mathrm{NO}_{\mathrm{x}}$, respectively, with the lower detection limits $0.5 \mathrm{ppb}, 50 \mathrm{ppb}, 0.5 \mathrm{ppb}$ and $0.5 \mathrm{ppb}$. All the trace gas instruments were maintained and calibrated routinely, and the measurements are reported with uncertainties of $1 \%$ on average. Meanwhile, an automatic meteorology station was operated to obtain meteorology parameters including temperature, relative humidity, pressure and radiation.

All the observed data are averaged to $10 \mathrm{~min}$ in order to be consistent with the particle number size distribution measurements. The measured parameters and instrumentation used in this study are listed in Table 1.

\subsection{Model description}

\subsubsection{MALTE}

For model simulations we used the zero-dimensional version of MALTE. The model structure is described in detail by Boy et al. (2006, 2008b) and Lauros et al. (2011). MALTE includes modules for canopy emission of organic compounds, gas-phase chemical reactions as well as aerosol physics. The emission module was disabled during our simulations, and instead the VOC concentrations obtained from PTRMS measurements (e.g. methanol, acetaldehyde, acetone, isoprene, methyl vinyl ketone (MVK) and methyl acrolein (MACR), methyl ethyl ketone (MEK), benzene, toluene, styrene, aromatic compounds including 8 and 9 carbon atoms respectively and monoterpenes) were used as input. Simultaneously GC-MS-FID measurements were used to estimate the separation of compounds with the same $m / z$ (MVK and MACR, the $\mathrm{C} 8$ aromatic compounds, the $\mathrm{C} 9$ aromatic compounds, and the monoterpenes). In addition, the atmospheric trace gases $\mathrm{SO}_{2}, \mathrm{NO}, \mathrm{NO}_{\mathrm{x}}, \mathrm{CO}, \mathrm{O}_{3}$ and the measured condensation sink (CS) for sulfuric acid were likewise used as input to the model.

\subsubsection{Chemistry}

Organic and inorganic chemical reactions were mostly selected from the MCM (Master Chemical Mechanism) v3.2 (Jenkin et al., 2003; Saunders et al., 2003) via the website:
http://mcm.leeds.ac.uk/MCM/. Meanwhile, additional reactions from Atkinson (1994) and Atkinson et al. (2004) were also included. The chemical equations (differential equations and compound concentrations) are calculated by the Kinetic PreProcessor (KPP) (Damian et al., 2002). The complete MCM reaction paths for methane, formaldehyde, methanol, acetaldehyde, acetone, isoprene, MVK, MACR, MEK, 2methyl-3-buten-2-ol (MBO), $\alpha$-pinene and $\beta$-pinene were included. Likewise, the full chemistry paths for the following aromatic compounds were included: benzene, toluene, styrene and the following $\mathrm{C} 8$-aromatic compounds: ethylbenzene, $o$-xylene and $m$-xylene, as well as the following C9-aromatic compounds: propylbenzene, 1-ethyl-2-methyl benzene, 1-ethyl-3-methyl benzene, 1-ethyl-4-methyl benzene, 1,3,5-trimethylbenzene and 1,2,4-trimethylbenzene. In addition, the first-order reactions between $\mathrm{OH}, \mathrm{O}_{3}, \mathrm{NO}_{3}$ and the following compounds were also included: cineole, ocimene, sabinene, camphene, myrcene, delta-3-carene, limonene, "other monoterpenes" than those mentioned here, $\beta$-caryophyllene, farnesene, and "other sesquiterpenes" than those mentioned here. Acetonitrile was also measured, but not included in the model simulations, due to unknown chemistry. Totally the chemistry included 2293 chemical species and 6604 reactions. Relevant research with more detailed description for the chemistry modelling part has been published by Mogensen et al. (2011).

\subsubsection{Aerosol}

Particle number size distribution patterns are estimated by the University of Helsinki Multicomponent Aerosol (UHMA) model, which is responsible for the aerosol dynamic simulation in MALTE. All the basic aerosol dynamic processes including nucleation, condensation, coagulation and dry deposition are implemented in the model (Korhonen et al., 2004). The UHMA model has been successful in predicting the new particle formation observed in forest and coastal environments (Boy et al., 2006; Vuollekoski et al., 2009). In the present study we use the fixed sectional approach with 36 size bins. The size of the critical cluster is set to $1.5 \mathrm{~nm}$ in the model according to field observations (Kulmala et al., 2007) and quantum chemical calculations (Zhang, 2010).

Both the activation $\left(J=A\left[\mathrm{H}_{2} \mathrm{SO}_{4}\right]\right)$ and kinetic nucleation $\left(J=K\left[\mathrm{H}_{2} \mathrm{SO}_{4}\right]^{2}\right)$ theories proposed in the ambient studies are first tested in the model. $A$ and $K$ refer to the activation and kinetic nucleation coefficients, respectively, with values of $3.0 \times 10^{-6} \mathrm{~s}^{-1}$ and $8.0 \times 10^{-13} \mathrm{~cm}^{3} \mathrm{~s}^{-1}$. These values are close to the measured median values of $17 \mathrm{NPF}$ event days during CAREBeijing 2008 (Wang et al., 2013b), however, several times higher compared to the results derived from other field measurements and model simulations in clean environments (Boy et al., 2008a; Paasonen et al., 2010; Riipinen et al., 2007; Wang et al., 2011). Recent research results indicate that sulfuric acid is not the 
Table 1. Atmospheric parameters and instrumentation from the CAREBeijing 2008 campaign that are used in this study.

\begin{tabular}{lll}
\hline Parameters & Instruments & Reference \\
\hline Particle number size distribution & TDMPS, IfT & Wehner et al. (2008) \\
Sulfuric acid & ID-CIMS, TA\&MU & Zheng et al. (2011) \\
VOCs & PTR-MS, Ionicon Analytik & Yuan et al. (2010) \\
$J_{\mathrm{O}^{1} \mathrm{D}} / J_{\mathrm{NO}_{2}}$ & Filter radiometer, METCON Inc. & Bohn et al. (2008) \\
$\mathrm{SO}_{2} / \mathrm{NO} / \mathrm{NO}_{\mathrm{x}} / \mathrm{CO} / \mathrm{O}_{3}$ & Gas analyzers, Ecotech Inc. & - \\
Pressure/temperature/relative humidity/radiation & M7115, LSI LASTEM s.r.l & - \\
\hline
\end{tabular}

only compound taking part in new particle formation, but low-volatile organic vapours are also needed (Kerminen et al., 2010; Lauros et al., 2011; Metzger et al., 2010; Riipinen et al., 2012). Here the homogenous heteromolecular nucleation mechanism, sulfuric acid-organic nucleation ( $\left.J=K_{\text {het }}\left[\mathrm{H}_{2} \mathrm{SO}_{4}\right][\mathrm{Org}]\right)$, is also tested in the model. However, the specific organic species involved in the nucleation process are still unclear. Therefore, following the previous studies (Laaksonen et al., 2008; Lauros et al., 2011; Paasonen et al., 2010), we assume that the organic vapours are the products of $\alpha$-pinene and $\beta$-pinene via $\mathrm{OH}$ radicals oxidation (MTOP). The nucleation coefficient $K_{\text {het }}$ ranges from $0.9 \times 10^{-12} \mathrm{~cm}^{3} \mathrm{~s}^{-1}$ to $8.0 \times 10^{-12} \mathrm{~cm}^{3} \mathrm{~s}^{-1}$. These values are two to three orders of magnitude higher than those in previous model simulations (Lauros et al., 2011), laboratory experiments (Metzger et al., 2010) as well as field studies (Paasonen et al., 2010).

The subsequent growth of newly formed particles is a crucial secondary transformation process. Both sulfuric acid and the oxidation products of organic components by reactions with $\mathrm{OH}$ are assumed as the condensing vapours according to the nano-Köhler theory (Kulmala et al., 2004a). In addition, water, sulfuric acid and reaction products of organic components, oxidized by $\mathrm{OH}, \mathrm{NO}_{3}$ and $\mathrm{O}_{3}$, participate in the conventional condensational growth of particles. For our model simulations, we have defined the condensing vapours as the first stable oxidation products for reactions between $\mathrm{OH}, \mathrm{O}_{3}, \mathrm{NO}_{3}$ and all the organic compounds for which we have included the full chemistry path. The molecular weights of the condensing molecules are $98 \mathrm{~g} \mathrm{~mol}^{-1}$ for sulfuric acid and $150 \mathrm{~g} \mathrm{~mol}^{-1}$ for the organic products, respectively. The diffusion volumes for the condensational vapours are set to $52 \mathrm{~cm}^{3} \mathrm{~mol}^{-1}$ in the model. Since no saturation vapour pressure estimation is currently included in our model, we have assumed that $0.5 \%$ of the concentration of the compounds that we have classified as being condensing vapours actually condenses onto the particles. This value is one order of magnitude lower compared with a previous study by Lauros et al. (2011). However, it leads to a good agreement with the observed growth rates.

Besides the gaseous species concentrations, meteorological parameters (temperature, relative humidity, pressure and radiation), photolysis rates $\left(J_{\mathrm{O}^{1} \mathrm{D}}\right.$ and $\left.J_{\mathrm{NO}_{2}}\right)$ as well as the initial particle number size distribution are also used as input variables. In total, 12 days with complete observation data, including 4 non-event days and 8 new particle formation event days, are investigated. The simulation time period is the entire day from 00:00 to 24:00. The integration time in the model is $10 \mathrm{~s}$, and the output data are averaged to $10 \mathrm{~min}$ in order to compare with the observation results.

\section{Results and discussion}

\subsection{The simulation of sulfuric acid concentration}

The condensation sink, which describes how rapidly vapour molecules can condense onto the pre-existing particles, is used to represent the sink term of sulfuric acid in the model. The CS values can be directly obtained from the measured particle number size distributions, and expressed as (Kulmala et al., 2001)

$\mathrm{CS}=2 \pi D \sum \beta D_{\mathrm{p}} N$.

Here, $D$ is the diffusion coefficient of the condensing vapour, $\beta$ the transitional regime correction factor, $D_{\mathrm{p}}$ the aerosol particle diameter and $N$ their number concentration. In addition, the particle number size distributions are calculated at ambient relative humidity, while the hygroscopic growth is achieved by using the parameterization of Massling et al. (2009) based on the measurement results in Beijing.

Figure 1 displays the measured and simulated sulfuric acid concentrations for 4 selected days including one nonevent day (day 219) and three nucleation event days (day 228, day 244 and day 256). The mean condensation sink (during 08:00-11:00) on a non-event day $\left(\mathrm{CS}=0.079 \mathrm{~s}^{-1}\right.$ ) is typically significantly higher than that on the three NPF event days, with mean values of $0.006 \mathrm{~s}^{-1}, 0.014 \mathrm{~s}^{-1}$ and $0.038 \mathrm{~s}^{-1}$, respectively, representing clean, median polluted and polluted situations. In general, the significant increase of the sulfuric acid concentration is observed from 8:00 with the peak shown at noon. A clear diurnal cycle of the modelled sulfuric acid concentration agrees to a large extent with the measurements (slope $=0.72$ during the daytime). The correlation coefficients between the observed and modelled sulfuric acid concentrations are 0.78 (morning) and 0.81 (afternoon) for the total 12 investigated cases (see Table 2), 
Table 2. Comparisons of the modelled and measured sulfuric acid concentrations during different time period for 12 investigated days. Slope represents the ratio between the modelled and observed sulfuric acid concentrations.

\begin{tabular}{lcc}
\hline Time period & Slope & $\begin{array}{c}\text { Correlation } \\
\text { coefficient }(R)\end{array}$ \\
\hline Morning (06:00-12:00) & 0.62 & 0.78 \\
Afternoon (12:00-18:00) & 0.88 & 0.81 \\
Daytime (06:00-18:00) & 0.72 & 0.74 \\
Nighttime (00:00-06:00 \& 18:00-24:00) & 0.32 & 0.53 \\
\hline
\end{tabular}

respectively. The maximum midday sulfuric acid concentrations vary between $3.1 \times 10^{6}$ and $1.1 \times 10^{7} \mathrm{~cm}^{-3}$ for the observations (all investigated day), corresponding to $1.2 \times 10^{6}$ to $1.0 \times 10^{7} \mathrm{~cm}^{-3}$ for the modelled results. The ratios of peak values between the observed and modelled concentrations are within a factor of 3 , with a median value of $1.3 \pm 0.6$.

In MALTE, the sulfuric acid concentrations are underestimated compared with the observations, especially during the morning rush hour. The modelled sulfuric acid concentrations only account for $62 \%$ of the observations (Table 2). One possible explanation is that we potentially underestimate the nitrous acid (HONO) concentration. The HONO concentrations were not measured continuously during the whole campaign; hence we did not use the measurement data as input in the model. A previous study (Kurtenbach et al., 2001) pointed out that traffic emissions can produce considerable HONO concentrations. Meanwhile, the photolysis of HONO is proved to be a significant source of the $\mathrm{OH}$ radical, especially in the early morning (Su et al., 2008). Direct measurements of HONO concentrations were only obtained in 3 days of the total 12 selected cases. On average, the observed HONO concentrations were one order of magnitude higher than the simulated ones during 06:00-12:00. Hence, the significant elevations of sulfuric acid concentrations were observed in the case of measured HONO concentrations as input data. As a result, the sulfuric acid concentrations could be enhanced by 1.5-2.5 times at the peak of around 08:00. Therefore, the lack of measured HONO concentrations in the model might lead to the substantial underestimation of sulfuric acid concentrations, especially at the urban site with heavy traffic emissions during the morning rush hour.

Best agreement between the modelled and observed sulfuric acid concentrations happened in the afternoon (during 12:00-18:00), with the slope of 0.88 . Overall, the modelled results correlate well with the measured data points during the daytime $(R=0.74)$ compared with that during the nighttime ( $R=0.53)$. This phenomenon is due to the lack of understanding of the nighttime chemistry. However, considering the NPF event has not been observed during the nighttime, the missing sulfuric acid in the nighttime will not be discussed further in this study.
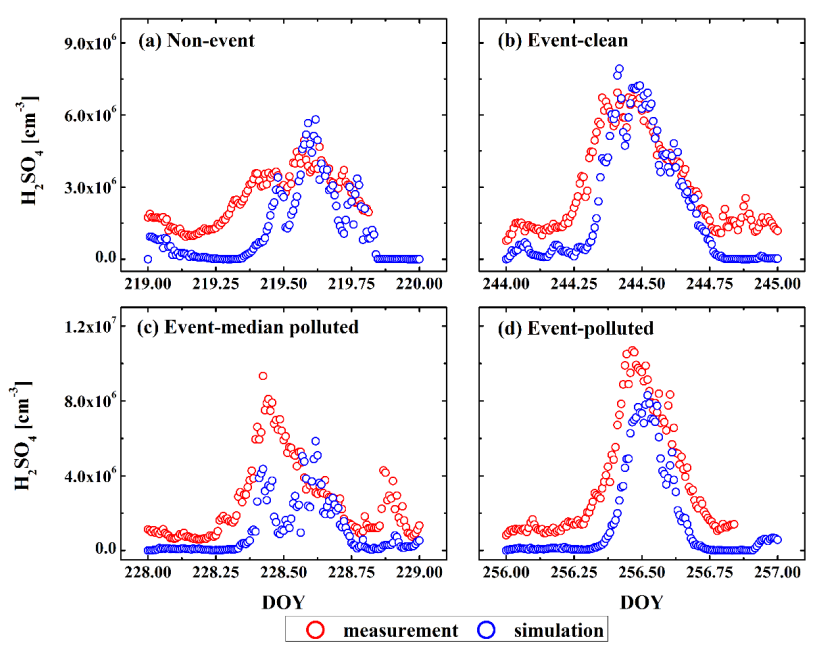

Fig. 1. Measured (red) and modelled (blue) sulfuric acid concentrations for four selected days in diverse pollution conditions. (a) Non-event day, (b, d) NPF event days. The $x$ axis is presented by DOY (day of year).

In MALTE, the underestimation of sulfuric acid concentrations, by up to a factor of two compared with the measurement, was also found in other sites such as Hyytiälä and Hohenpeissenberg (Boy et al., 2013). Several other potential routes to produce sulfuric acid in the ambient atmosphere have been proposed recently. The evidence from computational studies, field observations and laboratory experiments all shows that organic compounds such as Criegee intermediates or their derivatives have significant capacity to oxidize $\mathrm{SO}_{2}$ into $\mathrm{SO}_{3}$ rapidly, which might lead to an enhancement of gaseous sulfuric acid yields in the ambient atmosphere (Berndt et al., 2012; Boy et al., 2013; Kurtén et al., 2011; Mauldin III et al., 2012). Moreover, the $\mathrm{SO}_{2}$ oxidation involving electron-excited oxygen molecules could denote an additional source of sulfuric acid under specific conditions (Sorokin, 2010). However, these theories have not been applied in the box model version used at present, which might cause the underestimation of the modelled sulfuric acid concentration.

\subsection{The simulation of new particle formation}

The dates 6 August (day 219) and 12 September (day 256) are selected as examples of a non-event day and a NPF event day, respectively. Here the measured sulfuric acid concentrations are used in the UHMA model. The diurnal variations of particle number size distributions from the measurement and model simulation with two proposed nucleation mechanisms are presented in Fig. 2. The modelled on- and offset of new particle formation as well as the starting time of the NPF event are in good agreement with observations. The time shifts of the starting time of the NPF event between observation and simulation are achieved within half an hour in 

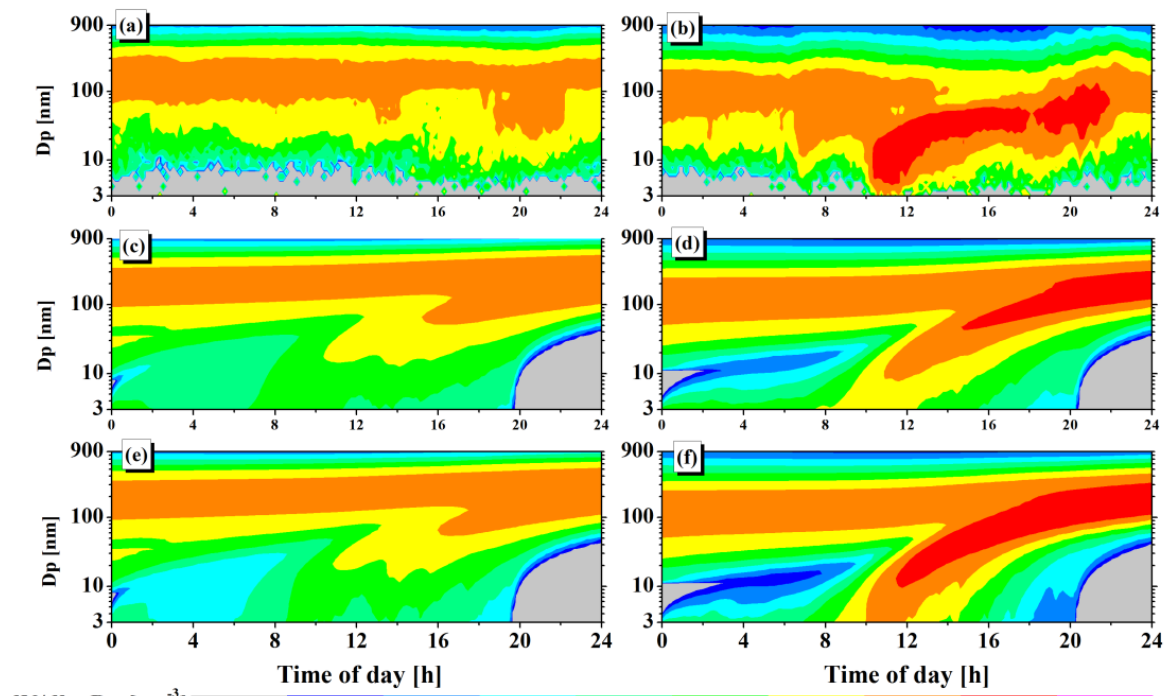

dN/dlogDp $\left[\mathrm{cm}^{-3}\right]$ Time of day $[\mathrm{h}]$

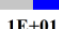

$1 \mathrm{E}+02$

$1 E+03$

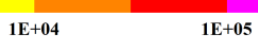

Fig. 2. Measured and modelled particle number size distributions for two selected days. Left panel represents the example of non-event day (6 August, day 219); right panel represents the example of a NPF event day (12 September, day 256); (a, b) measurement, (c, d) modelled with activation nucleation mechanism, $(\mathbf{e}, \mathbf{f})$ modelled with kinetic nucleation mechanism.

6 NPF cases (in total 8 cases). An obvious underestimation of the particle number concentration in the Aitken mode is observed in the model compared with the measurements. This might be attributed to the fact that the local traffic emissions are not completely included in the box model. Hence, following the previous study (Wang et al., 2011), the particle number concentration in the size range $3-6 \mathrm{~nm}\left(N_{3-6}\right)$ is selected to represent the newly formed particles in this study, as shown in Fig. 3. The slight fluctuations of $N_{3-6}$ from the simulation at noon are still observed even on the non-event day (Figs. 2c, e and 3a). However, the maximum value is only $700 \mathrm{~cm}^{-3}$, which is much lower than that on NPF event days. A better agreement between the observed and modelled $N_{3-6}$ on 12 September is found when the nucleation process is assumed as kinetic-type (see Fig. 3b). Although the increase of the simulated $N_{3-6}$ is 20 min earlier than that of the observation, the maximum value is $8000 \mathrm{~cm}^{-3}$, which is close to the ambient measurement $\left(9000 \mathrm{~cm}^{-3}\right)$. The peak of simulated $N_{3-6}$ values is only $2900 \mathrm{~cm}^{-3}$ on 12 September when activation nucleation is assumed. This result is expected because the specific activation nucleation coefficient achieved from the observed particle nucleation rates and sulfuric acid concentrations is $6 \times 10^{-6} \mathrm{~s}^{-1}$ on 12 September (Wang et al., 2011), which is twice as high compared with the value used in the model (median value of 17 NPF event days). Totally, the statistical results suggest that the model overestimates the number concentrations of newly formed particles on 4 nonevent days and underestimates them on 8 NPF event days. On average, the ratios between the observed and modelled maximum $N_{3-6}$ values in activation and kinetic nucleation types are $0.8 \pm 0.4$ and $0.7 \pm 0.5$ on non-event days, respectively. On the contrary, the ratios are $2.2 \pm 1.4$ and $1.5 \pm 1.3$ on NPF event days.

Besides the measured sulfuric acid, the modelled sulfuric acid concentrations were also tested in the UHMA model. The results showed that the on- and offset of new particle formation are also well predicted. However, it should be clarified that the strength of the nucleation event is decreased, which is due to the underestimation of sulfuric acid before noon, as we mentioned above. The ratios of maximum $N_{3-6}$ values between the cases that modelled and measured sulfuric acid used in MALTE are $0.78 \pm 0.40$ for activation nucleation and $0.64 \pm 0.44$ for kinetic nucleation, respectively, suggesting that the underestimation of sulfuric acid concentrations should be taken into consideration in the further simulation in case we do not have sulfuric acid measurements.

The modelled particle volume concentration in nucleation mode $\left(V_{3-25}\right)$ shows a similar growth pattern as observation on NPF event days. A significant time delay $(\sim 2 \mathrm{~h})$ between the simulated and observed $V_{3-25}$ is found. This might be attributed to the underestimation of $\mathrm{OH}$ concentrations before noon (06:00-12:00 a.m.). As a result, the ratios of maximum values between the simulated and measured $V_{3-25}$ are $0.8 \pm 0.3$ on NPF event days and $1.8 \pm 1.3$ on non-event days, respectively (see Fig. 4).

During the nucleation event, the fraction of $V_{3-25}$ contributed by the sulfuric acid is on average $3.2 \% \pm 1.6 \%$. This value is in the range of previous studies (Kuang et al., 2010; Stolzenburg et al., 2005; Wang et al., 2013b; Wehner et al., 2005), which suggests the limited contribution of 


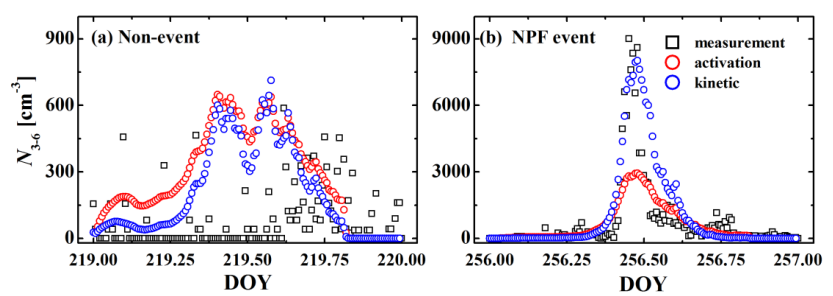

Fig. 3. Measured and modelled particle number concentrations in the size range $3-6 \mathrm{~nm}\left(N_{3-6}\right)$ for two selected days. (a) A nonevent day (6 August, day 219), (b) NPF event day (12 September, day 256); black square: measurement, red circle: modelled with activation nucleation mechanism, blue circle: modelled with kinetic nucleation mechanism.

gaseous sulfuric acid to particle growth. Totally, the $\mathrm{OH}$ and $\mathrm{O}_{3}$ oxidation mechanism contribute $5.5 \% \pm 2.3 \%$ and $94.5 \% \pm 2.6 \%$ to the $V_{3-25}$, respectively, indicating the particle growth is more controlled by the precursor gases and their oxidation by $\mathrm{O}_{3}$, which is consistent with the field observation (Yli-Juuti et al., 2011) and laboratory study (Hao et al., 2011).

Figure 5 displays the measured and modelled particle number size distributions using kinetic nucleation $(K=$ $8.0 \times 10^{-13}$ ) and homogenous heteromolecular nucleation $\left(K_{\text {het }}=3.0 \times 10^{-12}\right)$ theories. MALTE could predict the occurrence of new particle formation with the nucleation mechanism involving the organic vapours (Fig. 5c). In the model, the ultrafine particle mode is formed around 10:20 in the morning, which is close to the ambient measurement (10:10). The diurnal variations of number concentrations of newly formed particles are exhibited in Fig. 6. The maximum value of the modelled $N_{3-6}$ with homogenous heteromolecular nucleation is $8000 \mathrm{~cm}^{-3}$, which is the same as the modelled $N_{3-6}$ with kinetic nucleation and close to the ambient measurement $\left(9000 \mathrm{~cm}^{-3}\right)$. However, a significant time delay (about $2 \mathrm{~h}$ ) is shown between the model simulations and measurements. Therefore, the specific organic species possibly involved in the atmospheric nucleation are still unknown in the polluted urban environment of Beijing. More information on the nucleation process and chemical compositions of freshly formed particles is needed.

\section{Summary}

The box model version of MALTE, including gas-phase chemical reactions as well as aerosol physics and dynamics, was applied to predict the sulfuric acid concentration as well as the new particle formation in the polluted urban environment of Beijing, China. The chemical processes and aerosol dynamics were calculated by using MCM v3.2 and the UHMA code, respectively. Totally, 12 selected days ( 8 with new particle formation events and 4 without) with complete measurement data were investigated in this study.

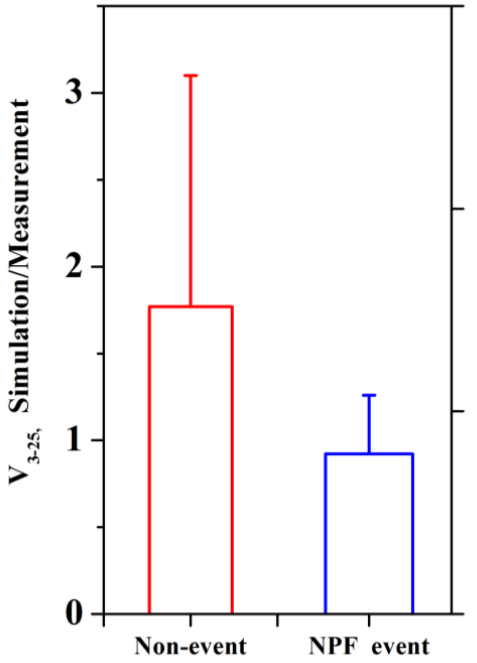

Fig. 4. The ratios between the simulated and measured particle volume concentration in nucleation mode $\left(V_{3-25}\right)$ on non-event (red) and NPF event (blue) days.

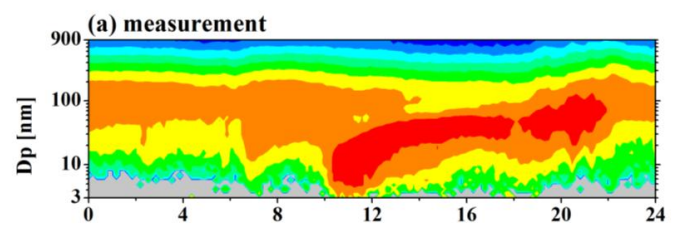

(b) $J=K\left[\mathrm{H}_{2} \mathrm{SO}_{4}\right]^{2}, K=8.0 \times 10^{-13} \mathrm{~cm}^{3} \mathrm{~s}^{-1}$

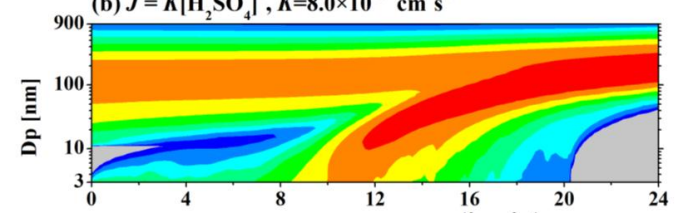

(c) $J=K_{\text {het }}\left[H_{2} \mathrm{SO} \mathrm{A}_{4} \mid[\mathrm{Org}], K_{\mathrm{het}}=3.0 \times 10^{-12} \mathrm{~cm}^{3} \mathrm{~s}^{-1}\right.$

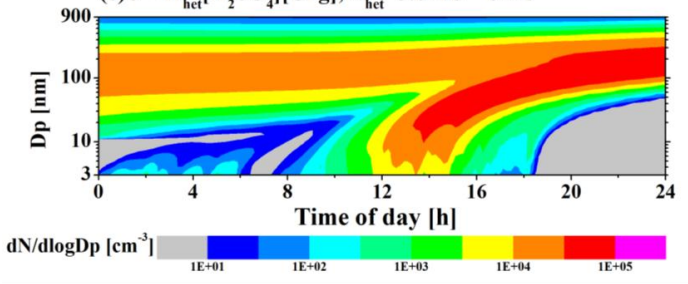

Fig. 5. Measured and modelled particle number size distributions on 12 September: (a) measurement, (b) modelled with kinetic nucleation mechanism, and (c) modelled with homogenous heteromolecular kinetic nucleation mechanism.

The best agreement (slope $=0.88, R=0.81$ ) between the measured and modelled sulfuric acid concentrations was seen in the afternoon (during 12:00-18:00). The sulfuric acid concentrations are significantly underestimated in the model compared with the measurements, especially during the morning rush hour and nighttime. This result indicates that unknown important production pathways of the $\mathrm{OH}$ radical or $\mathrm{SO}_{2}$ oxidation mechanisms are missing in the model, 


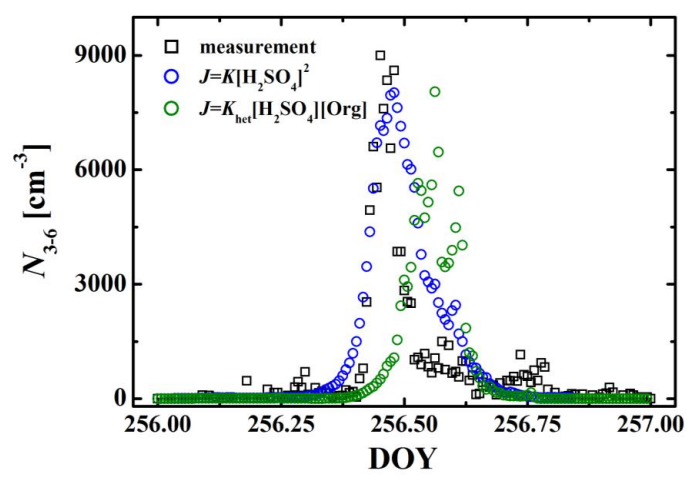

Fig. 6. Measured and modelled particle number concentrations in the size range 3-6 $\mathrm{nm}\left(N_{3-6}\right)$ on September 12. Black square: measurement, blue circle: modelled with kinetic nucleation mechanism, green circle: modelled with homogenous heteromolecular kinetic nucleation mechanism.

which might further lead to the underestimation of the sulfuric acid concentration. Although we have not included the recently proposed production paths for sulfuric acid into MALTE, the simulated sulfuric acid concentrations are acceptable during the daytime.

Classic nucleation mechanisms including activation nucleation and kinetic nucleation, with respective nucleation coefficients $3 \times 10^{-6} \mathrm{~s}^{-1}$ and $8 \times 10^{-13} \mathrm{~cm}^{3} \mathrm{~s}^{-1}$, were tested in the UHMA model. These values were several times higher compared to the results derived from other field measurements and model simulations in clean environments, implying that besides sulfuric acid, also other species such as lowvolatility organic vapours might be involved in the nucleation process in polluted urban Beijing. The model was able to reproduce the particle formation reasonably well under these two tested nucleation theories. The diurnal maximum number concentration of newly formed particles $\left(N_{3-6}\right)$ calculated based on the kinetic nucleation mechanism seems more reasonable, comparing with the activation nucleation. However, on average, it is still 1.2 times higher than that in ambient measurements for all investigated cases. Totally, the statistical results suggest that the model overestimates $N_{3-6}$ on non-event days and underestimates them on NPF event days.

During nucleation events, only a small fraction $(\sim 0.5 \%)$ of the oxidized total organics condense onto the particles. As the newly formed particles, the modelled particle volume concentrations in nucleation mode are overestimated on nonevent days and underestimated on NPF event days. On average, the $\mathrm{OH}$ and $\mathrm{O}_{3}$ oxidation mechanism contribute $5.5 \%$ and $94.5 \%$ to the volume concentration of small particles, respectively. This result indicates that the particle growth is more controlled by the precursor gases and their oxidation by $\mathrm{O}_{3}$.

Moreover, homogenous heteromolecular nucleation $(J=$ $\left.K_{\text {het }}\left[\mathrm{H}_{2} \mathrm{SO}_{4}\right][\mathrm{Org}]\right)$ was also tested in this study. The organic vapours involved in the nucleation process are assumed to be the oxidation products of monoterpenes by $\mathrm{OH}$ radicals. The diurnal patterns of particle number size distributions as well as the number concentrations of newly formed particles were close to the observation. However, a significant time delay of the number concentration peak is observed, implying that the specific organic components involved in the nucleation process still should be concerned in further research.

Acknowledgements. This work is supported by the National Natural Science Foundation of China (21025728, 21190052), the National Basic Research Program by the Ministry of Science and Technology (2013CB228503) and the China Ministry of Environmental Protection's Special Funds for Scientific Research on Public Welfare (201009002). The authors from University of Helsinki would like to acknowledge HENVI (Helsinki University Centre for Environment), while D. Mogensen would like to thank the doctoral program ACCC (Atmospheric Composition and Climate Change) for financial support. The authors also would like to thank Xiaoyang Liu and Jietai Mao (Department of Atmospheric and Oceanic Sciences, Peking University) for providing meteorological data.

Edited by: R. Krejci

\section{References}

Arnold, F. and Buhrke, T.: New $\mathrm{H}_{2} \mathrm{SO}_{4}$ and $\mathrm{HSO}_{3}$ vapour measurements in the stratosphere-evidence for a volcanic influence, Nature, 301, 293-295, 1983.

Arnold, F. and Fabian, R.: First measurements of gas phase sulphuric acid in the stratosphere, Nature, 283, 55-57, 1980.

Arnold, F., Viggiano, A. A., and Schlager, H.: Implications for trace gases and aerosols of large negative ion clusters in the stratosphere, Nature, 297, 371-376, 1982.

Atkinson, R.: Gas-phase tropospheric chemistry of organic compounds, J. Phys. Chem. Ref. Data, Monograph, 2, 1-216, 1994.

Atkinson, R., Baulch, D. L., Cox, R. A., Crowley, J. N., Hampson, R. F., Hynes, R. G., Jenkin, M. E., Rossi, M. J., and Troe, J.: Evaluated kinetic and photochemical data for atmospheric chemistry: Volume $\mathrm{I}$ - gas phase reactions of $\mathrm{O}_{\mathrm{x}}, \mathrm{HO}_{\mathrm{x}}, \mathrm{NO}_{\mathrm{x}}$ and $\mathrm{SO}_{\mathrm{x}}$ species, Atmos. Chem. Phys., 4, 1461-1738, doi:10.5194/acp-41461-2004, 2004.

Berndt, T., Böge, O., Stratmann, F., Heintzenberg, J., and Kulmala, M.: Rapid formation of sulfuric acid particles at near-atmospheric conditions, Science, 307, 698-700, doi:10.1126/science.1104054, 2005.

Berndt, T., Jokinen, T., Mauldin III, R. L., Petäjä, T., Herrmann, H., Junninen, H., Paasonen, P., Worsnop, D. R., and Sipilä, M.: GasPhase Ozonolysis of Selected Olefins: The Yield of Stabilized Criegee Intermediate and the Reactivity toward $\mathrm{SO}_{2}$, J. Phys. Chem. Lett., 3, 2892-2896, doi:10.1021/jz301158u, 2012.

Birmili, W., Stratmann, F., and Wiedensohler, A.: Design of a DMA-based size spectrometer for a large particle size range and stable operation, J. Aerosol Sci., 30, 549-553, doi:10.1016/S0021-8502(98)00047-0, 1999.

Bohn, B., Corlett, G. K., Gillmann, M., Sanghavi, S., Stange, G., Tensing, E., Vrekoussis, M., Bloss, W. J., Clapp, L. J., Kortner, 
M., Dorn, H.-P., Monks, P. S., Platt, U., Plass-Dülmer, C., Mihalopoulos, N., Heard, D. E., Clemitshaw, K. C., Meixner, F. X., Prevot, A. S. H., and Schmitt, R.: Photolysis frequency measurement techniques: results of a comparison within the ACCENT project, Atmos. Chem. Phys., 8, 5373-5391, doi:10.5194/acp-85373-2008, 2008.

Boy, M., Kulmala, M., Ruuskanen, T. M., Pihlatie, M., Reissell, A., Aalto, P. P., Keronen, P., Dal Maso, M., Hellen, H., Hakola, H., Jansson, R., Hanke, M., and Arnold, F.: Sulphuric acid closure and contribution to nucleation mode particle growth, Atmos. Chem. Phys., 5, 863-878, doi:10.5194/acp-5-863-2005, 2005.

Boy, M., Hellmuth, O., Korhonen, H., Nilsson, E. D., ReVelle, D., Turnipseed, A., Arnold, F., and Kulmala, M.: MALTE - model to predict new aerosol formation in the lower troposphere, Atmos. Chem. Phys., 6, 4499-4517, doi:10.5194/acp-6-4499-2006, 2006.

Boy, M., Karl, T., Turnipseed, A., Mauldin, R. L., Kosciuch, E., Greenberg, J., Rathbone, J., Smith, J., Held, A., Barsanti, K., Wehner, B., Bauer, S., Wiedensohler, A., Bonn, B., Kulmala, M., and Guenther, A.: New particle formation in the Front Range of the Colorado Rocky Mountains, Atmos. Chem. Phys., 8, 15771590, doi:10.5194/acp-8-1577-2008, 2008a.

Boy, M., Kazil, J., Lovejoy, E. R., Guenther, A., and Kulmala, M.: Relevance of ion-induced nucleation of sulfuric acid and water in the lower troposphere over the boreal forest at northern latitudes, Atmos. Res., 90, 151-158, doi:10.1016/j.atmosres.2008.01.002, $2008 \mathrm{~b}$

Boy, M., Mogensen, D., Smolander, S., Zhou, L., Nieminen, T., Paasonen, P., Plass-Dülmer, C., Sipilä, M., Petäjä, T., Mauldin, L., Berresheim, H., and Kulmala, M.: Oxidation of $\mathrm{SO}_{2}$ by stabilized Criegee intermediate $(\mathrm{sCI})$ radicals as a crucial source for atmospheric sulfuric acid concentrations, Atmos. Chem. Phys., 13, 3865-3879, doi:10.5194/acp-13-3865-2013, 2013.

Damian, V., Sandu, A., Damian, M., Potra, F., and Carmichael, G. R.: The kinetic preprocessor KPP-a software environment for solving chemical kinetics, Comput. Chem. Eng., 26, 1567-1579, doi:10.1016/s0098-1354(02)00128-x, 2002.

Eisele, F. L. and Tanner, D. J.: Measurement of the gas phase concentration of $\mathrm{H}_{2} \mathrm{SO}_{4}$ and methane sulfonic acid and estimates of $\mathrm{H}_{2} \mathrm{SO}_{4}$ production and loss in the atmosphere, J. Geophys. Res.Atmos., 98, 9001-9010, doi:10.1029/93jd00031, 1993.

Fortner, E. C., Zhao, J., and Zhang, R. Y.: Development of ion driftchemical ionization mass spectrometry, Anal. Chem., 76, 54365440, doi:10.1021/Ac0493222, 2004.

Hao, L. Q., Romakkaniemi, S., Yli-Pirilä, P., Joutsensaari, J., Kortelainen, A., Kroll, J. H., Miettinen, P., Vaattovaara, P., Tiitta, P., Jaatinen, A., Kajos, M. K., Holopainen, J. K., Heijari, J., Rinne, J., Kulmala, M., Worsnop, D. R., Smith, J. N., and Laaksonen, A.: Mass yields of secondary organic aerosols from the oxidation of a-pinene and real plant emissions, Atmos. Chem. Phys., 11, 1367-1378, doi:10.5194/acp-11-1367-2011, 2011.

Holmes, N. S.: A review of particle formation events and growth in the atmosphere in the various environments and discussion of mechanistic implications, Atmos. Environ., 41, 2183-2201, doi:10.1016/j.atmosenv.2006.10.058, 2007.

Jenkin, M. E., Saunders, S. M., Wagner, V., and Pilling, M. J.: Protocol for the development of the Master Chemical Mechanism, MCM v3 (Part B): tropospheric degradation of aromatic volatile organic compounds, Atmos. Chem. Phys., 3, 181-193, doi:10.5194/acp-3-181-2003, 2003.

Kerminen, V.-M., Petäjä, T., Manninen, H. E., Paasonen, P., Nieminen, T., Sipilä, M., Junninen, H., Ehn, M., Gagné, S., Laakso, L., Riipinen, I., Vehkamäki, H., Kurten, T., Ortega, I. K., Dal Maso, M., Brus, D., Hyvärinen, A., Lihavainen, H., Leppä, J., Lehtinen, K. E. J., Mirme, A., Mirme, S., Hõrrak, U., Berndt, T., Stratmann, F., Birmili, W., Wiedensohler, A., Metzger, A., Dommen, J., Baltensperger, U., Kiendler-Scharr, A., Mentel, T. F., Wildt, J., Winkler, P. M., Wagner, P. E., Petzold, A., Minikin, A., Plass-Dülmer, C., Pöschl, U., Laaksonen, A., and Kulmala, M.: Atmospheric nucleation: highlights of the EUCAARI project and future directions, Atmos. Chem. Phys., 10, 10829-10848, doi:10.5194/acp-10-10829-2010, 2010.

Korhonen, H., Lehtinen, K. E. J., and Kulmala, M.: Multicomponent aerosol dynamics model UHMA: model development and validation, Atmos. Chem. Phys., 4, 757-771, doi:10.5194/acp-4757-2004, 2004.

Kuang, C., McMurry, P. H., McCormick, A. V., and Eisele, F. L.: Dependence of nucleation rates on sulfuric acid vapor concentration in diverse atmospheric locations, J. Geophys. Res.-Atmos., 113, D10209, doi:10.1029/2007jd009253, 2008.

Kuang, C., Riipinen, I., Sihto, S.-L., Kulmala, M., McCormick, A. V., and McMurry, P. H.: An improved criterion for new particle formation in diverse atmospheric environments, Atmos. Chem. Phys., 10, 8469-8480, doi:10.5194/acp-10-8469-2010, 2010.

Kulmala, M. and Kerminen, V.-M.: On the formation and growth of atmospheric nanoparticles, Atmos. Res., 90, 132-150, doi:10.1016/j.atmosres.2008.01.005, 2008.

Kulmala, M., Laaksonen, A., and Pirjola, L.: Parameterizations for sulfuric acid/water nucleation rates, J. Geophys. Res.-Atmos., 103, 8301-8307, 1998.

Kulmala, M., Maso, M. D., Mäkelä, J. M., Pirjola, L., Väkevä, M., Aalto, P., Miikkulainen, P., Hämeri, K., and O'Dowd, C. D.: On the formation, growth and composition of nucleation mode particles, Tellus B, 53, 479-490, 2001.

Kulmala, M., Kerminen, V.-M., Anttila, T., Laaksonen, A., and O'Dowd, C. D.: Organic aerosol formation via sulphate cluster activation, J. Geophys. Res.-Atmos., 109, D04205, doi:10.1029/2003jd003961, 2004a.

Kulmala, M., Vehkamäki, H., Petäjä, T., Dal Maso, M., Lauri, A., Kerminen, V.-M., Birmili, W., and McMurry, P. H.: Formation and growth rates of ultrafine atmospheric particles: a review of observations, J. Aerosol Sci., 35, 143-176, doi:10.1016/j.jaerosci.2003.10.003, 2004b.

Kulmala, M., Lehtinen, K. E. J., and Laaksonen, A.: Cluster activation theory as an explanation of the linear dependence between formation rate of $3 \mathrm{~nm}$ particles and sulphuric acid concentration, Atmos. Chem. Phys., 6, 787-793, doi:10.5194/acp-6-787-2006, 2006.

Kulmala, M., Riipinen, I., Sipilä, M., Manninen, H. E., Petäjä, T., Junninen, H., Maso, M. D., Mordas, G., Mirme, A., Vana, M., Hirsikko, A., Laakso, L., Harrison, R. M., Hanson, I., Leung, C., Lehtinen, K. E. J., and Kerminen, V.-M.: Toward direct measurement of atmospheric nucleation, Science, 318, 89-92, doi:10.1126/science.1144124, 2007.

Kurtén, T., Lane, J. R., Jørgensen, S., and Kjaergaard, H. G.: A Computational Study of the Oxidation of $\mathrm{SO}_{2}$ to $\mathrm{SO}_{3}$ by Gas- 
Phase Organic Oxidants, J. Phys. Chem. A, 115, 8669-8681, doi:10.1021/jp203907d, 2011.

Kurtenbach, R., Becker, K. H., Gomes, J. A. G., Kleffmann, J., Lörzer, J. C., Spittler, M., Wiesen, P., Ackermann, R., Geyer, A., and Platt, U.: Investigations of emissions and heterogeneous formation of HONO in a road traffic tunnel, Atmos. Environ., 35, 3385-3394, doi:10.1016/s1352-2310(01)00138-8, 2001.

Laaksonen, A., Kulmala, M., O’Dowd, C. D., Joutsensaari, J., Vaattovaara, P., Mikkonen, S., Lehtinen, K. E. J., Sogacheva, L., Dal Maso, M., Aalto, P., Petäjä, T., Sogachev, A., Yoon, Y. J., Lihavainen, H., Nilsson, D., Facchini, M. C., Cavalli, F., Fuzzi, S., Hoffmann, T., Arnold, F., Hanke, M., Sellegri, K., Umann, B., Junkermann, W., Coe, H., Allan, J. D., Alfarra, M. R., Worsnop, D. R., Riekkola, M.-L., Hyötyläinen, T., and Viisanen, Y.: The role of VOC oxidation products in continental new particle formation, Atmos. Chem. Phys., 8, 2657-2665, doi:10.5194/acp-82657-2008, 2008.

Lauros, J., Sogachev, A., Smolander, S., Vuollekoski, H., Sihto, S.L., Mammarella, I., Laakso, L., Rannik, Ü., and Boy, M.: Particle concentration and flux dynamics in the atmospheric boundary layer as the indicator of formation mechanism, Atmos. Chem. Phys., 11, 5591-5601, doi:10.5194/acp-11-5591-2011, 2011.

Massling, A., Stock, M., Wehner, B., Wu, Z. J., Hu, M., Brüggemann, E., Gnauk, T., Herrmann, H., and Wiedensohler, A.: Size segregated water uptake of the urban submicrometer aerosol in Beijing, Atmos. Environ., 43, 1578-1589, doi:10.1016/j.atmosenv.2008.06.003, 2009.

Mauldin III, R. L., Berndt, T., Sipilä, M., Paasonen, P., Petäjä, T., Kim, S., Kurtén, T., Stratmann, F., Kerminen, V.-M., and Kulmala, M.: A new atmospherically relevant oxidant of sulphur dioxide, Nature, 488, 193-196, doi:10.1038/nature11278, 2012.

McMurry, P. H. and Friedlander, S. K.: New particle formation in the presence of an aerosol, Atmos. Environ., 13, 1635-1651, doi:10.1016/0004-6981(79)90322-6, 1979.

Merikanto, J., Spracklen, D. V., Mann, G. W., Pickering, S. J., and Carslaw, K. S.: Impact of nucleation on global CCN, Atmos. Chem. Phys., 9, 8601-8616, doi:10.5194/acp-9-8601-2009, 2009.

Metzger, A., Verheggen, B., Dommen, J., Duplissy, J., Prevot, A. S. H., Weingartner, E., Riipinen, I., Kulmala, M., Spracklen, D. V., Carslaw, K. S., and Baltensperger, U.: Evidence for the role of organics in aerosol particle formation under atmospheric conditions, P. Natl. Acad. Sci. USA, 107, 6646-6651, doi:10.1073/pnas.0911330107, 2010.

Mikkonen, S., Romakkaniemi, S., Smith, J. N., Korhonen, H., Petäjä, T., Plass-Duelmer, C., Boy, M., McMurry, P. H., Lehtinen, K. E. J., Joutsensaari, J., Hamed, A., Mauldin III, R. L., Birmili, W., Spindler, G., Arnold, F., Kulmala, M., and Laaksonen, A.: A statistical proxy for sulphuric acid concentration, Atmos. Chem. Phys., 11, 11319-11334, doi:10.5194/acp-11-11319-2011, 2011.

Mogensen, D., Smolander, S., Sogachev, A., Zhou, L., Sinha, V., Guenther, A., Williams, J., Nieminen, T., Kajos, M. K., Rinne, J., Kulmala, M., and Boy, M.: Modelling atmospheric OH-reactivity in a boreal forest ecosystem, Atmos. Chem. Phys., 11, 97099719, doi:10.5194/acp-11-9709-2011, 2011.

Napari, I., Noppel, M., Vehkamäki, H., and Kulmala, M.: An improved model for ternary nucleation of sulfuric acid-ammoniawater, J. Chem. Phys., 116, 4221-4227, doi:10.1063/1.1450557, 2002 .
Nieminen, T., Manninen, H. E., Sihto, S.-L., Yli-Juuti, T., Mauldin III, R. L., Petäjä, T., Riipinen, I., Kerminen, V.-M., and Kulmala, M.: Connection of Sulfuric Acid to Atmospheric Nucleation in Boreal Forest, Environ. Sci. Technol., 43, 4715-4721, doi:10.1021/Es803152j, 2009.

Paasonen, P., Sihto, S.-L., Nieminen, T., Vuollekoski, H., Riipinen, I., Plaß-Dülmer, C., Berresheim, H., Birmili, W., and Kulmala, M.: Connection between new particle formation and sulphuric acid at Hohenpeissenberg (Germany) including the influence of organic compounds, Boreal Environ. Res., 14, 616-629, 2009.

Paasonen, P., Nieminen, T., Asmi, E., Manninen, H. E., Petäjä, T., Plass-Dülmer, C., Flentje, H., Birmili, W., Wiedensohler, A., Hõrrak, U., Metzger, A., Hamed, A., Laaksonen, A., Facchini, M. C., Kerminen, V.-M., and Kulmala, M.: On the roles of sulphuric acid and low-volatility organic vapours in the initial steps of atmospheric new particle formation, Atmos. Chem. Phys., 10, 11223-11242, doi:10.5194/acp-10-11223-2010, 2010.

Petäjä, T., Mauldin, III, R. L., Kosciuch, E., McGrath, J., Nieminen, T., Paasonen, P., Boy, M., Adamov, A., Kotiaho, T., and Kulmala, M.: Sulfuric acid and $\mathrm{OH}$ concentrations in a boreal forest site, Atmos. Chem. Phys., 9, 7435-7448, doi:10.5194/acp9-7435-2009, 2009.

Riipinen, I., Sihto, S.-L., Kulmala, M., Arnold, F., Dal Maso, M., Birmili, W., Saarnio, K., Teinilä, K., Kerminen, V.-M., Laaksonen, A., and Lehtinen, K. E. J.: Connections between atmospheric sulphuric acid and new particle formation during QUEST III-IV campaigns in Heidelberg and Hyytiälä, Atmos. Chem. Phys., 7, 1899-1914, doi:10.5194/acp-7-1899-2007, 2007.

Riipinen, I., Yli-Juuti, T., Pierce, J. R., Petäjä, T., Worsnop, D. R., Kulmala, M., and Donahue, N. M.: The contribution of organics to atmospheric nanoparticle growth, Nat. Geosci., 5, 453-458, 2012.

Saunders, S. M., Jenkin, M. E., Derwent, R. G., and Pilling, M. J.: Protocol for the development of the Master Chemical Mechanism, MCM v3 (Part A): tropospheric degradation of nonaromatic volatile organic compounds, Atmos. Chem. Phys., 3, 161-180, doi:10.5194/acp-3-161-2003, 2003.

Sihto, S.-L., Kulmala, M., Kerminen, V.-M., Dal Maso, M., Petäjä, T., Riipinen, I., Korhonen, H., Arnold, F., Janson, R., Boy, M., Laaksonen, A., and Lehtinen, K. E. J.: Atmospheric sulphuric acid and aerosol formation: implications from atmospheric measurements for nucleation and early growth mechanisms, Atmos. Chem. Phys., 6, 4079-4091, doi:10.5194/acp-6-4079-2006, 2006.

Sipilä, M., Berndt, T., Petäjä, T., Brus, D., Vanhanen, J., Stratmann, F., Patokoski, J., Mauldin III, R. L., Hyvärinen, A.P., Lihavainen, H., and Kulmala, M.: The Role of Sulfuric Acid in Atmospheric Nucleation, Science, 327, 1243-1246, doi:10.1126/science.1180315, 2010.

Sorokin, A.: One conceivable mechanism of UV-light induced $\mathrm{SO}_{2}$ Oxidation to $\mathrm{H}_{2} \mathrm{SO}_{4}$, Atmos. Chem. Phys., 10, 3141-3145, doi:10.5194/acp-10-3141-2010, 2010.

Spracklen, D. V., Carslaw, K. S., Kulmala, M., Kerminen, V.-M., Sihto, S.-L., Riipinen, I., Merikanto, J., Mann, G. W., Chipperfield, M. P., Wiedensohler, A., Birmili, W., and Lihavainen, H.: Contribution of particle formation to global cloud condensation nuclei concentrations, Geophys. Res. Lett., 35, L06808, doi:10.1029/2007g1033038, 2008. 
Stolzenburg, M. R., McMurry, P. H., Sakurai, H., Smith, J. N., Mauldin, R. L., Eisele, F. L., and Clement, C. F.: Growth rates of freshly nucleated atmospheric particles in Atlanta, J. Geophys. Res., 110, D22S05, doi:10.1029/2005jd005935, 2005.

Su, H., Cheng, Y. F., Shao, M., Gao, D. F., Yu, Z. Y., Zeng, L. M., Slanina, J., Zhang, Y. H., and Wiedensohler, A.: Nitrous acid (HONO) and its daytime sources at a rural site during the 2004 PRIDE-PRD experiment in China, J. Geophys. Res.Atmos., 113, D14312, doi:10.1029/2007jd009060, 2008.

Vuollekoski, H., Kerminen, V.-M., Anttila, T., Sihto, S.-L., Vana, M., Ehn, M., Korhonen, H., McFiggans, G., O'Dowd, C. D., and Kulmala, M.: Iodine dioxide nucleation simulations in coastal and remote marine environments, J Geophys. Res.-Atmos., 114, D02206, doi:10.1029/2008jd010713, 2009.

Wang, B., Shao, M., Lu, S. H., Yuan, B., Zhao, Y., Wang, M., Zhang, S. Q., and Wu, D.: Variation of ambient non-methane hydrocarbons in Beijing city in summer 2008, Atmos. Chem. Phys., 10, 5911-5923, doi:10.5194/acp-10-5911-2010, 2010.

Wang, Z. B., Hu, M., Yue, D. L., Zheng, J., Zhang, R. Y., Wiedensohler, A., Wu, Z. J., Nieminen, T., and Boy, M.: Evaluation on the role of sulfuric acid in the mechanisms of new particle formation for Beijing case, Atmos. Chem. Phys., 11, 12663-12671, doi:10.5194/acp-11-12663-2011, 2011.

Wang, Z. B., Hu, M., Sun, J. Y., Wu, Z. J., Yue, D. L., Shen, X. J., Zhang, Y. M., Pei, X. Y., and Wiedensohler, A.: Characteristics of regional new particle formation in urban and regional background environments in the North China Plain, Atmos. Chem. Phys. Discuss., 13, 20531-20560, doi:10.5194/acpd-13-205312013, 2013a.

Wang, Z. B., Hu, M., Wu, Z. J., Yue, D. L., Zheng, J., Zhang, R. Y., Pei, X. Y., Paasonen, P., Dal Maso, M., Boy, M., and Wiedensohler, A.: Investigation of the connections between atmospheric new particle formation and organics at an urban site of Beijing, Atmos. Chem. Phys. Discuss., 13, 3419-3450, doi:10.5194/acpd-13-3419-2013, 2013 b.

Weber, R. J., Mcmurry, P. H., Eisele, F. L., and Tanner, D. J.: Measurement of Expected Nucleation Precursor Species and 3-500Nm Diameter Particles at Mauna-Loa-Observatory, Hawaii, J. Atmos. Sci., 52, 2242-2257, 1995.

Weber, R. J., Marti, J. J., McMurry, P. H., Eisele, F. L., Tanner, D. J., and Jefferson, A.: Measurements of new particle formation and ultrafine particle growth rates at a clean continental site, J. Geophys. Res.-Atmos., 102, 4375-4385, doi:10.1029/96JD03656, 1997.

Wehner, B., Petaja, T., Boy, M., Engler, C., Birmili, W., Tuch, T., Wiedensohler, A., and Kulmala, M.: The contribution of sulfuric acid and non-volatile compounds on the growth of freshly formed atmospheric aerosols, Geophys. Res. Lett., 32, L16801, doi:10.1029/2005g1023827, 2005.

Wehner, B., Birmili, W., Ditas, F., Wu, Z., Hu, M., Liu, X., Mao, J., Sugimoto, N., and Wiedensohler, A.: Relationships between submicrometer particulate air pollution and air mass history in Beijing, China, 2004-2006, Atmos. Chem. Phys., 8, 6155-6168, doi:10.5194/acp-8-6155-2008, 2008.

Wiedensohler, A., Cheng, Y. F., Nowak, A., Wehner, B., Achtert, P., Berghof, M., Birmili, W., Wu, Z. J., Hu, M., Zhu, T., Takegawa, N., Kita, K., Kondo, Y., Lou, S. R., Hofzumahaus, A., Holland, F., Wahner, A., Gunthe, S. S., Rose, D., Su, H., and Pöschl, U.: Rapid aerosol particle growth and increase of cloud condensation nucleus activity by secondary aerosol formation and condensation: A case study for regional air pollution in northeastern China, J. Geophys. Res.-Atmos., 114, D00G08, doi:10.1029/2008jd010884, 2009.

Wiedensohler, A., Birmili, W., Nowak, A., Sonntag, A., Weinhold, K., Merkel, M., Wehner, B., Tuch, T., Pfeifer, S., Fiebig, M., Fjäraa, A. M., Asmi, E., Sellegri, K., Depuy, R., Venzac, H., Villani, P., Laj, P., Aalto, P., Ogren, J. A., Swietlicki, E., Williams, P., Roldin, P., Quincey, P., Hüglin, C., Fierz-Schmidhauser, R., Gysel, M., Weingartner, E., Riccobono, F., Santos, S., Grüning, C., Faloon, K., Beddows, D., Harrison, R., Monahan, C., Jennings, S. G., O’Dowd, C. D., Marinoni, A., Horn, H.-G., Keck, L., Jiang, J., Scheckman, J., McMurry, P. H., Deng, Z., Zhao, C. S., Moerman, M., Henzing, B., de Leeuw, G., Löschau, G., and Bastian, S.: Mobility particle size spectrometers: harmonization of technical standards and data structure to facilitate high quality long-term observations of atmospheric particle number size distributions, Atmos. Meas. Tech., 5, 657-685, doi:10.5194/amt5-657-2012, 2012.

Wu, Z. J., Hu, M., Lin, P., Liu, S., Wehner, B., and Wiedensohler, A.: Particle number size distribution in the urban atmosphere of Beijing, China, Atmos. Environ., 42, 7967-7980, doi:10.1016/j.atmosenv.2008.06.022, 2008.

Yli-Juuti, T., Nieminen, T., Hirsikko, A., Aalto, P. P., Asmi, E., Hõrrak, U., Manninen, H. E., Patokoski, J., Dal Maso, M., Petäjä, T., Rinne, J., Kulmala, M., and Riipinen, I.: Growth rates of nucleation mode particles in Hyytiälä during 20032009: variation with particle size, season, data analysis method and ambient conditions, Atmos. Chem. Phys., 11, 12865-12886, doi:10.5194/acp-11-12865-2011, 2011.

Yu, F. Q. and Turco, R. P.: Ultrafine aerosol formation via ionmediated nucleation, Geophys. Res. Lett., 27, 883-886, 2000.

Yuan, B., Liu, Y., Shao, M., Lu, S. H., and Streets, D. G.: Biomass Burning Contributions to Ambient VOCs Species at a Receptor Site in the Pearl River Delta (PRD), China, Environ. Sci. Technol., 44, 4577-4582, doi:10.1021/Es1003389, 2010.

Yue, D. L., Hu, M., Zhang, R. Y., Wu, Z. J., Su, H., Wang, Z. B., Peng, J. F., He, L. Y., Huang, X. F., Gong, Y. G., and Wiedensohler, A.: Potential contribution of new particle formation to cloud condensation nuclei in Beijing, Atmos. Environ., 45, 6070-6077, doi:10.1016/j.atmosenv.2011.07.037, 2011.

Zhang, R., Khalizov, A., Wang, L., Hu, M., and Xu, W.: Nucleation and Growth of Nanoparticles in the Atmosphere, Chem. Rev., 112, 1957-2011, doi:10.1021/cr2001756, 2012.

Zhang, R. Y.: Getting to the Critical Nucleus of Aerosol Formation, Science, 328, 1366-1367, doi:10.1126/science.1189732, 2010.

Zheng, J., Khalizov, A., Wang, L., and Zhang, R.: Atmospheric Pressure-Ion Drift Chemical Ionization Mass Spectrometry for Detection of Trace Gas Species, Anal. Chem., 82, 7302-7308, doi:10.1021/ac101253n, 2010.

Zheng, J., Hu, M., Zhang, R., Yue, D., Wang, Z., Guo, S., Li, X., Bohn, B., Shao, M., He, L., Huang, X., Wiedensohler, A., and Zhu, T.: Measurements of gaseous $\mathrm{H}_{2} \mathrm{SO}_{4}$ by AP-ID-CIMS during CAREBeijing 2008 Campaign, Atmos. Chem. Phys., 11, 7755-7765, doi:10.5194/acp-11-7755-2011, 2011. 